\title{
SYSTEM MOTYWACJI JAKO KLUCZOWY CZYNNIK KSZTAŁTOWANIA KAPITAŁU LUDZKIEGO
}

\section{WSTĘP}

W dzisiejszych czasach, kiedy mamy do czynienia z doskonaleniem techniki i technologii rozwijają się kompetencje ludzi. Jednakże, współczesny człowiek przybiera różne postawy dotyczące poszerzania swoich kompetencji. Jedni są bardziej aktywni inni mniej. Motywacja zewnętrzna, jak i wewnętrzna jest kluczowym czynnikiem procesu samodoskonalenia się pracowników. Nie każdy pracownik ma tyle samozaparcia żeby motywować się do bardziej efektywnej pracy. Celem organizacji jest zmotywowanie takich osób, zainwestowanie w kapitał ludzki, co w efekcie przyniesie korzyści firmie i pracownikom. Artykuł ma na celu ukazać czynniki wspomagające kształtowanie kapitału ludzkiego poprzez system motywacji.

\section{ZNACZENIE KAPITAŁU LUDZKIEGO}

Pojęcie kapitału ludzkiego jako pierwszy użył Schultz w 1961 roku. Definiował go jako zbiór wrodzonych lub nabytych cech ludzkich poprzez edukację i różne szkolenia, cenionych w organizacji ${ }^{1}$. Schultz uważał, że każdy człowiek rodzi się z pewną pulą genów, które decydują o jego zdolnościach. Za pomocą odpowiedniego kształcenia wzbogacają się i tworzą kapitał ludzki.

Tradycyjna teoria kapitału ludzkiego posługuje się modelami, w których zakłada się, że kapitał ludzki ma charakter homogeniczny, a swoim zakresem obejmuje on

\footnotetext{
* Studentka, przewodnicząca Studenckiego Koła Naukowego „HRM”, Uniwersytet Łódzki.

1 www.pifhprofit.com.pl/?id_akt $=129 \&$ status $=3$ [dostęp dnia: 9.05.2015].
} 
nie tylko ludzką wiedzę i umiejętności, ale także zdrowie, punktualność i uczciwość. W modelach tych kapitał ludzki traktowany jest jako autonomiczny czynnik produkcji, który można mierzyć i sumować².

Współczesne definicje podkreślają, że kapitał ludzki odzwierciedla czynnik ludzki w organizacji: „to połączenie inteligencji, umiejętności i fachowości, stanowiących o odrębnym charakterze organizacji"3. A. Pocztowski kapitał ludzki określa jako ogół cech i właściwości ucieleśnionych w ludziach (wiedzę, umiejętności, zdolności, zdrowie, motywację), które mają określoną wartość oraz stanowią źródło przyszłych dochodów zarówno dla pracownika-właściciela kapitału ludzkiego, jak i dla organizacji korzystającej z tegoż kapitału na określonych warunkach4. Pomimo różnorodności w definiowaniu kapitału ludzkiego przez różnych autorów, można wyznaczyć kilka cech niezmiennych, cenionych przez każdego z nich, a konkretnie kapitał ludzki jest:

- nierozerwalnie związany z jednostką, z jej cechami fizycznymi, intelektualnymi, moralnymi, psychicznymi,

- zarządzanie nim musi przebiegać z zachowaniem praw jednostek.

Budowanie kapitału ludzkiego polega na inwestowaniu w żywego człowieka, a nie $w$ martwe przedmioty ${ }^{5}$. Należy dodać, że postawy reprezentowane przez pracownika, potencjał i przyjęte zasady są kreowane przez kulturę organizacyjną danego przedsiębiorstwa, która według niektórych traktowana jest jako element kapitału ludzkiego ${ }^{6}$. Pierwiastek ludzki w organizacji to taki, który wprowadza zmiany, innowacje, działa nowatorsko, świeżo, szybko się uczy i który odpowiednio zmotywowany zapewni długotrwale istnienie organizacji.

\section{MOTYWACJA JAKO CZYNNIK KSZTAŁTOWANIA KAPITAŁU LUDZKIEGO}

Pojęcie motywacji nie ma jednoznacznej interpretacji. Termin „motywacja” pochodzi od łacińskiego słowa „motivus”, co w języku polskim oznacza skłaniający do ruchu, pobudzający do działania7. O skuteczności pracowników na płaszczyźnie zawodowej decyduje wiele elementów, m.in. wynagrodzenie, atmosfera w pra-

2 M. Tyrańska, Współczesne tendencje w zarządzaniu zasobami ludzkimi, Difin SA, Warszawa 2012, s. 97.

3 N. Bontis, The Knowledge Toolbox: A Review of the Tools Available to Measure and Manage Intangible Resources, „European Management Journal” 1999, Vol. 17, No. 4, s. 391-402, [w:] M. Armstrong, Zarządzanie zasobami ludzkimi, Oficyna Ekonomiczna, Kraków 2007, s. 323.

4 A. Pocztowski (red.), Zarządzanie zasobami ludzkimi w procesach fuzji i przejęć, Oficyna Ekonomiczna, Kraków 2004, s. 171.

5 Ibidem, s. 98.

6 www.pifhprofit.com.pl/?id_akt $=129 \&$ status $=3$ [dostęp: 9.05.2015].

7 Słownik Wyrazów Obcych, PWN, Warszawa 1991, s. 578. 
cy, uznanie przełożonych, premie, pochwały. „Motywowanie jest definiowane jako oddziaływanie w procesie zarządzania na pracownika, ukierunkowuje jego działania na realizację celów organizacji ${ }^{\circ}$. Warto zwrócić uwagę, że „motywacja jest nie tylko siłą motoryczną ludzkich zachowań i działań, jest ona również niezbędnym i jednym z najważniejszych czynników wzrostu efektywności pracy"9. Motywowanie w zarządzaniu zasobami ludzkimi jest często pomijane. Wielu pracodawców zaniedbuje swój personel pod względem motywowania, uważając, że przy aktualnej sytuacji na rynku pracy i wysokim bezrobociu, sam fakt posiadania pracy jest motywujący. „Motywacja odnosi się do przeżyć psychicznych człowieka. Stanowi ona proces regulacji, który pełni funkcję sterowania czynnościami tak, aby prowadziły do osiągnięcia określonego celu"10. Definicji motywacji w literaturze jest wiele, jedną z nich jest podana przez Sprengera, który sprowadza ją do czterech krótkich stwierdzeń:

- wyposażenie kogoś w bodźce do określonego działania, których wcześniej nie miał,

- stworzenie możliwości w realizacji ludzkich motywów postępowania,

- obarczenie sposobu zachowania jednostki pewnego rodzaju znaczeniem,

- rozbudzenie entuzjazmu i zachęcenie do działania.

Według innej „motywowaniem pracowników nazywa się pobudzenie ludzi do określonych zachowań nastawionych na cele firmy za pomocą takich bodźców, które będą zaspokajać ich potrzeby"11. Od rozmiaru i schematu motywacji zależy ogólna aktywność psychofizyczna jednostki, mobilizacja jej sił i energii. Aktualny stan wiedzy psychologicznej przewiduje trzy założenia dotyczące zachowań człowieka:

- jest powodowane oddziaływaniem określonych czynników,

- zawsze związane jest z jakimś celem,

- można na nie oddziaływać12.

W kwestii dotyczących zachowań człowieka pewnego rodzaju metodą stała się teoria potrzeb A.H. Maslowa, która wyróżnia 5 poziomów potrzeb uporządkowanych według ich ważności.

Według Maslowa ludźmi kierują dwie zasady:

1. Zasada deficytu - jeśli pracownik jest przekonany, że dana potrzeba będzie przez dłuższy czas zaspokajana, przestaje ona odgrywać rolę czynnika motywującego.

2. Zasada rozwoju - po zaspokojeniu wszystkich potrzeb zostaje jedynie potrzeba samorealizacji (pracownicy dążą do zwiększenia swoich kwalifikacji).

8 M. Zieliński, Kadry i płace w przedsiębiorstwie, GSWP, Gliwice 2011, s. 115.

9 J. Kaczmarzyk, Motywowanie jako determinanta efektywności pracy kadry menedżerskiej, Promotor, Warszawa 2006, s. 9.

10 L. Kozioł, M. Tyrańska, Motywowanie pracowników w teorii i praktyce, Biblioteczka Pracownicza, Warszawa 2002, s. 13.

11 J. Kaczmarzyk, Motywowanie jako determinanta efektywności..., s. 10.

12 L. Kozioł, M. Tyrańska, Motywowanie pracowników..., s. 13-14. 


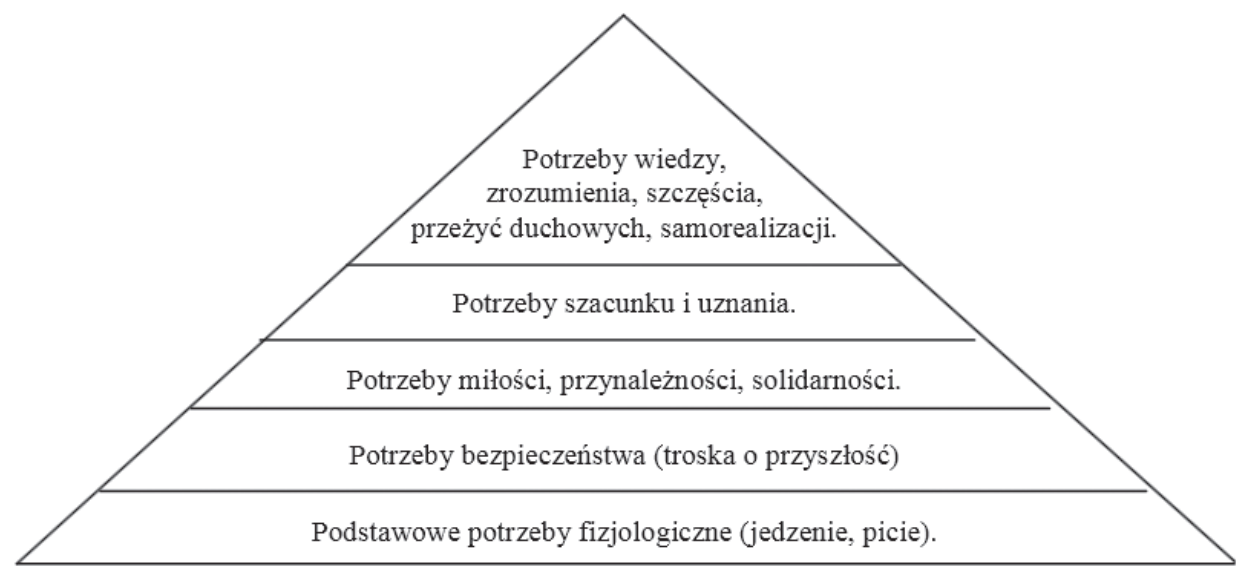

Rysunek 1. Piramida hierarchii potrzeb według Maslowa

ŹRóDŁo: www.wycieczkiznami.pl/panel-edukacyjny/14,wprowadzenie-do-ekonomii [dostęp: 9.05.2015]

Mimo że teoria Maslowa zyskała uznanie wśród menedżerów, nie została ona w pełni potwierdzona w praktyce. Każdy człowiek jest inny i jego potrzeby są zmienne. Jednakże, menedżerowie powinni znać i umieć rozpoznawać potrzeby swoich pracowników, żeby móc skutecznie ich motywować. Celem organizacji w krótkim czasie powinno być zaspokojenie potrzeb pracowników niższego rzędu, np. odpowiedniego wynagrodzenia, godziwych warunków pracy, dobrej atmosfery w pracy. Umożliwi to skupienie się na potrzebach wyższego rzędu, których zaspokojenie wzbudzi w pracowniku aktywną postawę oraz systematyczną, efektywną chęć wykonywania swojej pracy $^{13}$.

Alderfer uważał, że człowieka do pracy motywują niezaspokojone potrzeby. Wskazał trzy następujące grupy potrzeb:

- potrzeby egzystencji (potrzeby takie jak: głód, sen, wynagrodzenie),

- potrzeby społeczne (włączenia się w stosunki społeczne),

- indywidualne potrzeby wzrostu (rozwoju osobowości).

Teoria Alderfera wskazuje pewne właściwości w postępowaniu człowieka, których znajomość może prowadzić do skuteczniejszego motywowania. Aktywność człowieka może mieć swoje przyczyny w występowaniu w tym samym czasie potrzeb z kilku grup, np. chęć zawarcia umowy o pracę, samodoskonalenia i włączenia się w stosunki społeczne z współpracownikami. Koncepcja ta ma lepszy wydźwięk od teorii Maslowa, co może stanowić fundament teoretyczny do motywowania pracowników w organizacji. Mimo różnych koncepcji potrzeb kluczowe jest, to żeby menedżerowie

13 J. Kaczmarzyk, Motywowanie jako determinanta..., s. 14-16. 
zdawali sobie sprawę z tego, że ich pracownicy mogą mieć zróżnicowane potrzeby i zaspokojenie tych potrzeb ma wpływ na ich zachowanie i efektywność ${ }^{14}$.

Motywowanie to schemat działania, pewien proces dążący do zaspokajania potrzeb poprzez różne czynniki motywacyjne. Wdrożenie adekwatnego systemu motywacyjnego jest jednym z podstawowych zadań należących do osób zarządzających przedsiębiorstwem i kapitałem ludzkim. Poniżej przedstawiono tabelę opisującą czynniki motywacyjne.

Tabela 1. Narzędzia motywowania

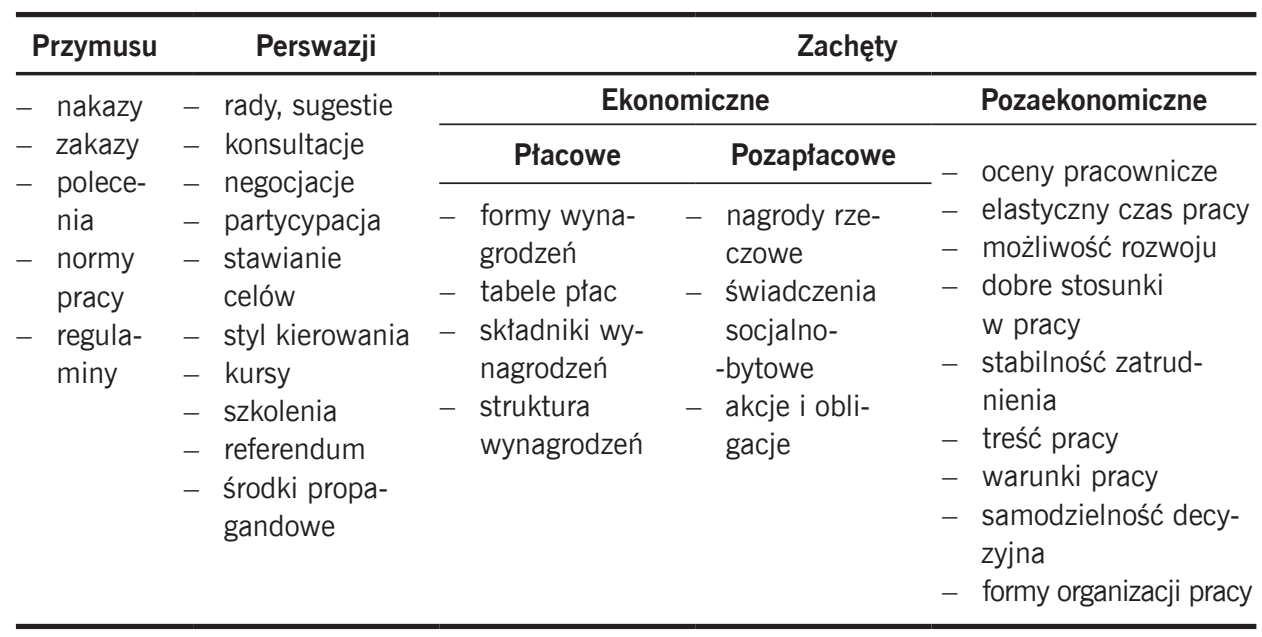

ŹRóDŁo: oprac. własne na podstawie: B. Kamińska, Materialne i nie materialne narzędzia motywowania pracowników, SWSPiZ, Łódź 2011, s. 67-68.

Zastosowanie w organizacji systemów motywacyjnych tworzy czynniki oddziałujące na pracowników, jednakże dobór odpowiedniego systemu motywacyjnego nie jest prostym zadaniem. Najbardziej popularnymi narzędziami motywowania są środki płacowe i pozapłacowe.

\section{PŁACOWE FORMY MOTYWOWANIA}

Do podstawowych form płac zalicza się:

1. Czasową formę płac - polega ona na opłacaniu pracy płacą zasadniczą oraz stałymi dodatkami. Bezpośrednio decyduje o wysokości indywidualnego wynagrodzenia.

2. Czasowo-premiową formę płac, polegającą na opłacaniu pracy płacą zasadniczą oraz premią. Rodzaj tego wynagrodzenia również może zawierać dodatki. Istotą

14 Ibidem, s. 16. 
jest opłacanie wymagań pracy - płacami zasadniczymi, a efektów - premiami. Jest to najbardziej uznana forma płac w przedsiębiorstwach.

3. Akordową formę płac, która bazuje na opłacaniu pracowników proporcjonalnie do wykonywania przez nich reguły pracy. Opłacany jest wynik, a nie czas poświęcony na wykonywanie pracy. Jednostką miary jest ilość wykonywanej pracy (sztuk, metrów, kilogramów itp.); w jednostce czasu pracy (godzinie, zmianie roboczej itp.).

4. System akordowy, którego atutem jest to, że działa jako bodziec efektywności pracy oraz jest miernikiem bezpośredniego stosunku płacy z pracą pracownika.

5. Akordowo-premiową postać płac, która opiera się na wykorzystywaniu, oprócz akordowego opłacenia wydajności pracy, premii za jakość produktu lub oszczędności materiałów. W pracy wymiernej ilościowo, źle wykonana praca jest nie opłacalna, co stanowi impuls do wysokiej wydajności z dążeniem do dobrej jakości towaru.

6. Czasowo-prowizyjną formę płac, bazującą na opłacaniu pracy płacą zasadniczą uzupełnioną o prowizję. Warunki uzyskania prowizji i jej kwotowy wymiar są dokładnie określone i mierzalne (mają wymiar rzeczowy lub finansowy).

7. Prowizyjną formę płac, jest ona zbliżona do umowy o dzieło. Zapewnia ona wynagrodzenie tylko wtedy, gdy pracownik spełnił wymogi uzyskania prowizji, (forma ta nie obejmuje opłacania godzin nadliczbowych oraz pracy w nocy).

8. Bonusową formę płac, opierającą się na stosowaniu ruchomej motywacyjnej części wynagrodzenia, powiązanej z efektami pracy. Sposób gratyfikacji w różnych firmach jest odmienny, jednak najczęściej jest to premia:

- premia płacona z zysku (w Polsce tzw „trzynastka” co oznacza jedną dodatkową wypłatę)

- premia liczona w koszty produkcji zależna od osiągniętego zysku. Traktowana jest jako czasowo-premiowa forma płac, gdzie miarą premii jest zysk ${ }^{15}$.

Systemy wynagradzania powinny zawierać wyniki osiągane przez firmę jako całość. Stabilność elementów wynagradzania stwarza u pracowników poczucie bezpieczeństwa, co z kolei może budować lepsze relacje interpersonalne, a w efekcie inspiruje do bardziej efektywnej pracy.

\section{POZAPŁACOWE NARZĘDZIA MOTYWOWANIA}

Kolejną formą motywowania pracowników są pozapłacowe instrumenty motywowania. Dobry menedżer nie powinien ograniczać się do „kupowania” motywacji. Motywację pracowników trzeba pobudzać do działania i kształtować, budując taką atmosferę, aby pracownicy lubili i szanowali swoje miejsce pracy. Do pozapłacowych środków pobudzania motywacji wliczamy wszystko, co pracownik otrzymuje od pracodawcy. Najpopularniejsze z nich przedstawiono w tabeli 2.

15 B. Kamińska, Materialne i niematerialne narzędzia motywowania pracowników, SWSPiZ, Łódź 2011, s. 67-68. 
Tabela 2. Pozapłacowe czynniki motywowania

\begin{tabular}{llll}
\hline \multicolumn{1}{c}{ Materialne } & \multicolumn{3}{c}{ Pozamaterialne } \\
\hline Szkolenia, rozwój & Obszar organizacyjny & Obszar psychologiczny & Obszar techniczny \\
\cline { 2 - 4 } Świadczenia o charak- & Awanse, władza, & Pochwały, wyróżnienia, & Komfort pracy \\
terze socjalnym: wcza- & samodzielność, dostęp & praca w firmie o wy- & - nowoczesne \\
sy, wycieczki, festyny, & do informacji, praca & sokim prestiżu, praca & maszyny, bezpie- \\
przyjęcia okazjonalne & wymagająca kreatyw- & w dobrym zespole, & czeństwo pracy, \\
Ubezpieczenia & ności, elastyczny czas & komunikacja, samo- & warunki/ \\
Opieka medyczna & pracy, organizacja & realizacja, poczucie & standardy pracy \\
Przywileje np. samo- & pracy & bezpieczeństwa & \\
chód służbowy, telefon & & & \\
\hline
\end{tabular}

ŹRóDŁO: oprac. własne.

Czynniki wymienione w tabeli są wynikiem odczuwania przez pracowników czterech rodzajów potrzeb, tj:

- szacunku i uznania,

- więzi z innymi,

- twórczej aktywności,

- samodoskonalenia.

Dla pracowników cenne są również świadczenia rzeczowe. Podkreślają one dodatkowo prestiż zajmowanego stanowiska pracy i firmy.

Do tej grupy można zaliczyć m.in.:

- korzystanie z samochodu służbowego do celów służbowych i prywatnych (jego wartość jest uzależniona od wysokości stanowiska, niekiedy jest on niezbędny do pracy, np. dla przedstawicieli handlowych),

- opłaty telefoniczne, wyposażenie w telefon komórkowy,

- prenumerata czasopism,

- towary firmy przeznaczone dla pracowników za darmo bądź ze zniżką,

- opłaty mieszkaniowe,

- pożyczki,

- firmowe obiady,

- ubezpieczenia, opieka lekarska (Medicover, LuxMed),

- korzystanie z siłowni, rekreacja, relaks,

- szkolenia językowe,

- doradztwo finansowe i prawne,

- Incentive tips, tzn. wycieczki motywacyjno-integracyjne.

W organizacjach rozpowszechniło się zapraszanie na wycieczki zagraniczne specjalistów i kierowników, gdzie często łączy się pracę z wypoczynkiem. 
Osoby spoza miejsca wykonywania pracy mają możliwość skorzystania z wynajętych mieszkań blisko miejsca pracy.

Jeśli firma jest ulokowana w zatłoczonym miejscu w centrum, miejsca parkingowe dla pracowników są bardzo cenione, komputer do pracy w domu ${ }^{16}$.

\section{MOTYWACJA WEWNĘTRZNA I ZEWNĘTRZNA}

Wyróżnia się dwa rodzaje motywacji:

1. Wewnętrzną - trwałe zaangażowanie człowieka w realizację zadania jest możliwe jedynie, gdy uzna on zadanie za sensowne i uzasadnione;

2. Zewnętrzną - środek prowadzący do celu. Praca jako źródło zdobywania środków do zapewnienia sobie zdrowia i bezpieczeństwa, uznania wśród znajomych, życiowego komfortu. „Motywacja zewnętrzna oddziałuje bezpośrednio na zachowanie człowieka, jednak słabnie niepodtrzymywana motywacją wewnętrzną i trwa tak długo, jak długo dostarczany jest bodziec ją podtrzymujący"17.

„Motywacja wewnętrzna jest powodowana czynnikami pochodzącymi z wnętrza człowieka, występuje ona w różnych formach. Do najważniejszych należą:

- zamiłowanie i zainteresowanie pracą,

- zaangażowanie w zadanie,

- utożsamienie się z instytucją,;

- przyswojone normy i zasady"18.

Psycholog Woodworth jako pierwszy poruszył temat motywacji wewnętrznej. Twierdził m.in., że aktywność może być zainicjowana przez zewnętrzny motyw, ale przebiega swobodnie i efektywnie tylko wtedy, gdy jednostka nią kieruje i oddaje się jej z zaangażowaniem ${ }^{19}$.

Kolejne ważne komponenty motywacji wewnętrznej to poczucie autonomii i kompetencji oraz zainteresowanie i zaangażowanie. Potrzebę autonomii i kompetencji opisuję teoria autodeterminacji Deciego i Ryana. Opiera się ona na trzech kluczowych potrzebach psychologicznych:autonomii, kompetencji i relacji z ludźmi. Potrzeba autonomii wiąże się z poczuciem człowieka, że jest przyczyną zdarzeń, że ma możliwość wyboru, co go bardziej wewnętrznie motywuje do działania. Potrzeba kompetencji to

16 www.motywowanie-pracownikow.eprace.edu.pl/535,Pozaplacowe_srodki_pobudzania_ motywacji.html [dostęp: 12.05.2015].

17 J. Żuchowski, Narzędzia i metody doskonalenia jakości, Politechnika Radomska, Radom 2004, s. 29.

18 J. Penc, Role i umiejętności menedżerskie: sekrety sukcesu i kariery, Difin, Warszawa 2005, s. 243.

19 R.S. Woodworth, Dynamic Psychology, Columbia University Press, New York 1918, [w:] A. Lipka, M. Król, S. Waszczak, A. Winnicka-Wejs, Kształtowanie motywacji wewnętrznej, Difin, Warszawa 2010, s. 18. 
pragnienie bycia pożytecznym. Wykonywana czynność powinna stanowić wyzwanie dla człowieka na miarę jego możliwości. Dzięki takim wymogom pracownik staje się bardziej otwarty na nowe doświadczenia, aktywizuję się, posiada większą chęć do nauki. Kolejnym ważnym punktem są potrzeby relacji z ludźmi i przynależności. Odnosi się to do relacji interpersonalnej, doświadczenia opieki i troski, przyjmowanie cudzych standardów zachowań, akceptacji społeczneje ${ }^{20}$.

Motywacje wewnętrzną można również charakteryzować poprzez zainteresowanie przedmiotem czynności. Zainteresowanie jest elementem motywacji, ukierunkowanym na określony przedmiot, a nie tylko na samą czynność (np. ktoś czyta książkę ulubionego autora, ponieważ lubi jego twórczość, ale również lubi czytać). Dlatego też najbardziej skuteczną formą motywowania pracowników jest adekwatne zaprojektowanie przypisywanych stanowiskom pracy zadań pracy. Kontrolowanie, rywalizacja, nagrody pieniężne wywierają niekorzystny wpływ na motywacje wewnętrzną. Tego typu działania są bardziej efektywne przy motywacji zewnętrznej. Z kolei werbalne nagrody (pochwały, pozytywne oceny czy informacje zwrotne) zwiększają wymiar motywacji wewnętrznej. Nagrody mogą mieć negatywny wpływ, gdy np. pracownicy oczekują ich w trakcie wykonywania zadania, a uzyskują je dopiero po ukończeniu swojej pracy. Przypuszczalnie pozytywna ocena w trakcie wykonywania pracy polepsza poczucie kompetencji i poprawia efektywność. Istotę motywacji wewnętrznej tworzy chęć jednostki do podejmowania i kontynuowania czynności ze względu na samą czynność, a nie przyczyny zawarte w celach czy skutkach tej czynności, z czym mamy do czynienia przy motywacji zewnętrznejej.

\section{EFEKTYWNOŚĆ PROJEKTOWANIA MOTYWUJĄCYCH TREŚCI PRACY}

Do określenia efektów motywacji niezbędna jest analiza i ocena uzyskanych postępów w efektywności. Cel motywowania może być osiągnięty w różnym stopniu lub pozostawać poza możliwościami działającego, choćby w danym okresie. Efektywność motywowania autotelicznego może być definiowana w sposób:

- bezwzględny - zestawienie rzeczywistego i pożądanego stadium efektów i nakładów na projektowanie treści pracy w celu pobudzenia motywacji wewnętrznej. Stwierdzenie ekonomicznej opłacalności motywowania oraz działania ku jej zwiększeniu;

- względny (relatywny, porównawczy) - zestawienie kilku wariantów oddziaływania motywacyjnego wyróżniających się wielkością nakładów i efektów, zrealizowanych np. w odniesieniu do różnych członków zespołu i nakierowanie na wariant najlepiej rokujący ${ }^{22}$.

20 R.M. Ryan, E.L. Deci, On Happiness and Human Potencials: A Review of Research on Hedonic and Eudaimonic Well-Being, "Annual Review of Psychology" 2001, vol. 52, s. 141-166, [w:] A. Lipka, M. Król, S. Waszczak, A. Winnicka-Wejs, Kształtowanie motywacji..., s. 19-21.

\footnotetext{
21 Ibidem, s. 22-25.
}

22 Ibidem, s. 136-138. 
Skuteczne motywatory sprawiają, że pracobiorcy bardziej angażują się w swoją pracę i nie traktują jej jako zło konieczne. Najprostszym sposobem na zbadanie zaangażowania i potrzeb pracowników są kwestionariusze. Każdy system w przedsiębiorstwie musi być sprawdzony i oceniony pod względem efektywności. Systemy motywowania określa się stopniem zbieżności między oczekiwaniami pracownika a tym, co może od owego systemu uzyskać. Kiedy rozbieżności są duże, może to doprowadzić do niewskazanych zachowań, np. stronienie/niechęć do pracy. Jednakże, kiedy rozbieżności są małe lub czynniki motywujące odpowiadają potrzebom pracownika, skutkuje to ukierunkowaniem tych zachowań na osiąganie wyznaczonych celów i satysfakcji z pracy. Do każdego pracownika w miarę możliwości powinno dopasowywać się indywidualny system narzędzi motywowania. Potrzeby ludzkie są jednak zmienne, raz efektywnie dobrany instrument motywowania może przestać być adekwatny do aktualnej sytuacji pracownika. Ponieważ oczekiwania pracowników mogą ulegać szybkim zmianom ilościowym i jakościowym, należy przeprowadzać okresowe badania efektywności systemów motywowania. Takie oceny polegają na pomiarze poziomu zaspokojenia potrzeb pracowników. Jedną z popularnych form pomiaru jest metoda Nadlera i Lawlera, bazująca na teorii oczekiwań. Polega ona na analizowaniu problemów motywacji w organizacji, mierząc postawy indywidualnych pracowników. Etapy tej procedury polegają na przygotowaniu badania poprzez ustalenie grupy stanowisk, które wezmą udział w analizie, następnie przygotowuje się odpowiednią ilość kwestionariuszy oraz zawiadamia pracowników o celach badania. Kolejnym krokiem jest zebranie informacji za pomocą kwestionariusza składającego się z trzech części: A, B i C.

Część A polega na zapoznaniu się z ogólną sytuacją w systemie motywacji, która aktualnie jest badana, część B ma na celu poznanie indywidualnych oczekiwań pracowników w stosunku do pracy, część C umożliwia rozpoznanie ogólnie pojętej sytuacji organizacji pracy w badanej części przedsiębiorstwa.

Na końcu zlicza się wyniki oraz analizuje i ocenia. Dzięki tym działaniom można wyciągnąć wnioski na temat adekwatności aktualnego systemu motywowania oraz jego poszczególnych elementów. Ten schemat działania pozwala na ustalenie poziomu zaspokojenia potrzeb i oczekiwań pracowników. Dodatkowo ważne jest zbadanie motywacji wewnętrznej do pracy. Można ją przeanalizować przy pomocy kwestionariusza MAPP (Motywacyjna Analiza Potencjału Zawodowego). MAPP bazuje na 71 triadach przedstawiających różne sytuacje zawodowe ${ }^{23}$. „Technika MAPP nie bada umiejętności, lecz motywacje do wykonywania danego rodzaju pracy. Motywacje są pierwotne wobec umiejętności. Zatem badając motywację, docieramy do źródeł zachowań człowieka. Możemy przy tym stwierdzić, jaki jest wszechstronny potencjał zawodowy danej osoby, a nie tylko jej bieżące kompetencje i kwalifikacje"24. Dzięki tej technice można uzyskać informacje o preferencjach badanego, dotyczące treści i charakteru pracy, czym taka osoba lubi się zajmować w pracy oraz czego unika.

23 J. Kaczmarzyk, Motywowanie jako determinanta..., s. 41-42.

24 www.treco.pl/narzedzia/diagnozy-szczegoly/kategoria/indywidualna/id/297/motywacyjna-analiza potencjalu-pracowniczego-mapp-tm [dostęp: 12.05.2015]. 


\section{PODSUMOWANIE}

Rozwój i uatrakcyjnienie pracy poprzez systemy motywowania ma na celu zmniejszenie niezadowolenia pracowników z wykonywania rutynowych zadań w pracy. Nagradzanie pracowników może wpłynąć na ich efektywność i motywację w pracy. Premiowanie daje zadowolenie, wzrost aktywności w pracy oraz pewność, że zadowolony pracobiorca nie będzie szukał innej posady. Jeśli nagrody przyznawane będą za konkretne osiągnięcia pracownika, to skłaniać go będą do bardziej wytężonej pracy. Nagrody płacowe, jak i pozapłacowe, uznaniowe, utwierdzają pracownika w jego kompetencjach i dają poczucie własnej wartości. Każda organizacja poprzez narzędzia motywowania kształtuje kapitał ludzki. Celem motywowania jest zachęcenie pracowników do określonego działania, które przynosi korzyści dla organizacji, jak i dla właściciela kapitału ludzkiego. Ważnymi elementami skutecznego systemu motywacyjnego i wzrostu aktywności i zaangażowania pracowników w firmie jest takie zarządzanie pracą, aby pracownicy mieli poczucie autonomii i chęć ciągłego doskonalenia w osiągnięciu perfekcji. Budowanie systemów motywacji nie jest łatwe, ale dla wzmocnienia więzi pracowniczych i czerpania korzyści z efektywnej pracy warto wprowadzić je do organizacji. Podsumowując, zmotywowany pracownik może więcej. Człowiek potrzebuje wyzwań, pochwał i samorealizacji. Pracodawca, znając potrzeby pracownika, przy dobrym systemie motywacyjnym, poprzez konkretne czynniki może zarządzać tak kapitałem ludzkim, aby stało się źródłem korzyści dla niego i pracownika.

\section{BIBLIOGRAFIA}

Armstrong M., Zarządzanie zasobami ludzkimi, Kraków 2007.

Kaczmarzyk J., Motywowanie jako determinanta efektywności pracy kadry menedżerskiej, Promotor, Warszawa 2006.

Kamińska B., Materialne i niematerialne narzędzia motywowania pracowników, SWSPiZ, Łódź 2011.

Kozioł L., Tyrańska M., Motywowanie pracowników w teorii i praktyce, Biblioteczka Pracownicza, Warszawa 2002.

Lipka A., Król M., Waszczak S., Winnicka-Wejs A., Kształtowanie motywacji wewnętrznej, Difin, Warszawa 2010.

Penc J., Role i umiejętności menedżerskie: sekrety sukcesu i kariery, Difin, Warszawa 2005. Pocztowski A. (red.), Zarządzanie zasobami ludzkimi w procesach fuzji i przejęć, Oficyna Ekonomiczna, Kraków 2004.

Słownik Wyrazów Obcych, PWN, Warszawa 1991.

Tyrańska M., Wspótczesne tendencje w zarządzaniu zasobami ludzkimi, Difin SA, Warszawa 2012.

Zieliński M., Kadry i płace w przedsiębiorstwie, GSWP, Gliwice 2011.

Żuchowski J., Narzędzia i metody doskonalenia jakości, Politechnika Radomska, Radom 2004. 


\section{Źródła internetowe}

www.motywowaniepracownikow.eprace.edu.pl/535,Pozaplacowe_srodki_pobudzania_motywacji.html

http://www.pifhprofit.com.pl/?id_akt $=129 \&$ status $=3$

http://www.treco.pl/narzedzia/diagnozyszczegoly/kategoria/indywidualna/id/297/motywacyjna-analiza-potencjalu-pracowniczego-mapp-tm 